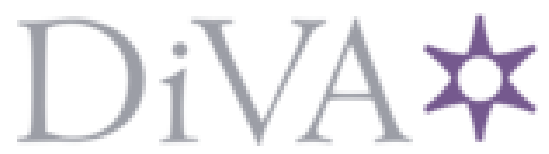

http://www.diva-portal.org

This is the published version of a paper published in Immunoendocrinology.

Citation for the original published paper (version of record):

Faresjö, M. (2016)

Children diagnosed with both type 1 diabetes and celiac disease - an Immunological challenge.

Immunoendocrinology, 3: 1-12

http://dx.doi.org/10.14800/ie.1110

Access to the published version may require subscription.

N.B. When citing this work, cite the original published paper.

Open Access Journal: http://www.smartscitech.com/index.php/ie/

Permanent link to this version:

http://urn.kb.se/resolve?urn=urn:nbn:se:hj:diva-29253 


\title{
Children diagnosed with both type 1 diabetes and celiac disease -an Immunological challenge
}

\author{
Maria Faresjö \\ Jönköping University, School of Health and Welfare, Department of Natural Science and Biomedicine, The Biomedical Platform, \\ S-551 11 Jönköping, Sweden and Division of Medical Diagnostics, Region Jönköping County, S-551 85 Jönköping, Sweden
}

Correspondence: Maria Faresjö

E-mail: maria.faresjo@ju.se

Received: November 11, 2015

Published online: January 11, 2016

\begin{abstract}
Type 1 diabetes (T1D) and celiac disease are both characterized by an autoimmune feature. As T1D and celiac disease share several common risk factors such as environment, genetics and immune dysregulation, patients have risk of developing the other disease subsequently. Patients with manifest T1D may have had a latent celiac disease, which is activated parallel to the anti-islet immune reactivity during the development of T1D. Contrary, a low prevalence of $\beta$-cell autoimmunity is found in young patients with celiac disease. The role of antigen-specific $T$ cells and their relation to cytokines and chemokines is not well characterized in children with combination of T1D and celiac disease. Defective regulation and an impaired ability of responder $T$ cells to be suppressed are suggested to contribute. We have previously shown that children suffering from these two immunological diseases in combination have a suppressed immune response to several antigens for example food antigens like gluten. Poor development of oral tolerance seen as immune aberrancies with low percentages of both early and late effector memory $\mathrm{CD8}^{+}$cells in the gut of children who are prone to T1D may predispose for development of celiac disease. This review highlights the immunological complexity in these two common pediatric immunological disorders that indicates that the combination of type 1 diabetes and celiac disease is an immunological challenge. It is obvious that we are far from understanding the immunological impact of these two autoimmune diseases in combination. This immunological challenge therefore needs to be elucidated to be able to predict and prevent these autoimmune diseases.
\end{abstract}

Keywords: type 1 diabetes; celiac disease; children, immune system; immune response

To cite this article: Maria Faresjö. Children diagnosed with both type 1 diabetes and celiac disease -an Immunological challenge. Immunoendocrinology 2016; 3: e1110. doi: 10.14800/ie.1110.

Copyright: () 2016 The Authors. Licensed under a Creative Commons Attribution 4.0 International License which allows users including authors of articles to copy and redistribute the material in any medium or format, in addition to remix, transform, and build upon the material for any purpose, even commercially, as long as the author and original source are properly cited or credited.

The cell-mediated part of the immune system

\section{T-helper and T-cytotoxic cells}

The obvious goal for the immune system is to protect us from viruses, bacteria and parasites invading our body. For this purpose the immune system keeps a number of different sorts of immune cells for example T-helper (Th; $\left.\mathrm{CD}^{+}\right)$, T-cytotoxic ( $\left.\mathrm{Tc} ; \mathrm{CD} 8^{+}\right)$and T-regulatory (Treg; $\mathrm{CD}^{+} \mathrm{CD} 25^{+} \mathrm{FoxP} 3^{+} \mathrm{CD} 127^{-}$) cells. T-helper as well as $\mathrm{Tc}$ cells differentiate from naïve cells to central memory and later on to effector memory cells. Memory $\mathrm{CD}^{+}$and $\mathrm{CD} 8^{+} \mathrm{T}$ cells can be further divided into subpopulations by their expression of CD27 and CD28 and further differentiated by 
expression of CD45RA and CCR7 into the subsets; naïve $\left(\mathrm{CD} 27^{+} \mathrm{CD} 28^{+} \mathrm{CD} 45 \mathrm{RA}{ }^{+} \mathrm{CCR} 7^{+}\right)$, effector memory ( $\left.\mathrm{T}_{\mathrm{EM}}\right)$ by early differentiation $\left(\mathrm{CD} 27^{+} \mathrm{CD} 28^{+} \mathrm{CD} 45 \mathrm{RA}^{-\mathrm{CCR}} 7^{-}\right)$or late differentiation (CD27-CD28-CD45RA-CCR7-), central memory $\left(\mathrm{T}_{\mathrm{CM}}, \quad \mathrm{CD} 27^{+} \mathrm{CD} 28^{+} \mathrm{CD} 45 \mathrm{RA}^{-} \mathrm{CCR} 7^{+}\right)$, or as terminally differentiated (TEMRA) (CD27-CD28-CD45RA ${ }^{+}{ }^{-}{ }^{-}{ }^{-} 7^{-}$) cells ${ }^{[1]}$.

\section{Cytokine and chemokine production by T-helper and T-cytotoxic cells}

Naïve $\mathrm{T}$ cells can differentiate into for example T-helper cells, upon interaction with antigen-presenting cells in a specific cytokine milieu, focusing on helping other cells in the immune system. The original paradigm of two distinct subpopulations of Th cells; Th1 and Th2 cells have during the last decade been expanded to include also Th3, Th9, Th17 and Th22 cells based upon for example their lineage-specific production of cytokines and chemokines.

T-helper 1 together with Th2 cells were the first two subpopulations to be described by Mosmann et al in $1986^{[2]}$. Naïve T cells, in a cytokine context of interleukin (IL)-12 and interferon (IFN)- $\gamma$, presented for an antigen by dendritic cells will differentiate into Th1 cells. Activation of Th1 cells by signal transducer and activator of transcription (STAT)-4 and T-box expressed in T cells (T-bet) will cause cytokine secreting of especially IFN- $\gamma$, IL- 2 and tumor necrosis factor (TNF) ${ }^{[3,4]}$ and promote cell-mediated immunity for example cytotoxic and inflammatory responses mediated by macrophages, natural killer (NK) and T cells.

T-helper 2 cells require the transcription factors STAT6 and the zinc-finger GATA3 ${ }^{[5]}$ as well as IL-4 and IL-33 for expansion and thereby produce a panel of different cytokines for example the interleukins; IL-4, IL-5, IL-6, IL-9, IL-10 and IL-13 ${ }^{[6]}$. These Th 2 cells and their secreted cytokines are important players in humoral immunity for example antibody production by B-cells and enhanced eosinophil proliferation. Thus, human Th1 and Th2 cells produce certain patterns of cytokines, although the characterization of Th subpopulations are not as tightly restricted as found in animal models. Cytokines derived by Th1 and Th2 cells also exert their effects in collaboration with cytokines elaborated by other subsets of Th cells.

The concept of Th1 and Th2 immunity can also be detailed by their different sets of chemokine receptors and chemokine production allowing them to migrate to different tissues. Chemokines can be broadly divided into two categories: inflammatory, which are induced or strongly upregulated in peripheral tissue by inflammation; and constitutive, which fulfil housekeeping functions and may be involved in constitutive leukocyte traffic ${ }^{[7]}$. Different sets of chemokine receptors are expressed on Th cells. The chemokines; C-C motif ligand (CCL) 2 (monocyte chemoattractant protein (MCP)-1) ${ }^{[8]}$, CCL3 (macrophage inflammatory protein (MIP)-1 $\alpha$ ), CCL4 (MIP-1 $\beta$ ) and CCL5 (regulated on activation, normal $\mathrm{T}$ cell expressed and secreted (RANTES)) are often discussed in relation to Th1 immunity. However, CCL5 binds to the promiscuous receptor $\mathrm{C}-\mathrm{C}$ motif receptor (CCR5) found to be expressed on Th1 cells but also found on Th2 cells ${ }^{[9]}$. Also CCL3 and CCL4 bind to the receptor CCR5 ${ }^{[9]}$ which illustrate the complexity of chemokines and their receptors.

Suppression of proliferation of Th1 and Th2 cells can be conducted for example by T-helper 3 cells, a subgroup of T-regulatory cells, through administration of TGF- $\beta$. Interleukin-10 with the concurrent inhibition of IL-12 may also augment the expansion of Th 3 cells by decreasing the development and maturation of Th1 cells, which in contrary can inhibit Th3 cell expansion ${ }^{[10]}$.

Naïve $\mathrm{T}$ cells can turn into T-helper 9 cells by activation of the cytokines transforming growth factor (TGF)- $\beta$ and IL-4 ${ }^{[11,12]}$ together with the promotor region of PU.1 from the ETS-family and the transcription factors STAT6, GATA3 and interferon response factor (IRF) $4^{[13]}$. These Th9 cells are identified by especially their production of IL-9 ${ }^{[12]}$ but also production of IL-10, IL-17, IL-21 and IL-22 even though their role for function of Th9 cells is still undiscovered ${ }^{[14,15]}$. Interleukin-9 has been associated with both allergic and autoimmune diseases ${ }^{[16]}$. Contrary, recent studies in animal models suggests a protective function of IL-9 in cancer for example by inhibiting tumor growth in a mast cell-dependent manner ${ }^{[17]}$.

Interleukin-9, together with TGF- $\beta$, have shown able to in vitro differentiate naïve $\mathrm{CD} 4^{+} \mathrm{T}$ cells into $\mathrm{T}$-helper 17 cells. In a so-called positive autocrine loop the production of IL-9 by Th17 cells can themselves amplify further Th17 cells ${ }^{[18]}$. Differentiation of naïve $\mathrm{T}$ cells into Th17 cells also require TGF- $\beta$ and IL- 6 and the nuclear receptor RAR-related orphan receptor (ROR) $-\mathrm{C}$ for its initial Th17 polarization. Also the interleukins IL-1 $\beta$, IL-6, IL-21 and IL-23 are shown to be involved in the differentiation of Th17 cells. T-helper 17 cells themselves produce especially IL-17A, IL-17F, IL-21, IL-22 and granulocyte macrophage colony-stimulating factor (GM-CSF) ${ }^{[19,20]}$, are identified as effector cells [21] and suggested to be involved in the pathogenesis of autoimmune diseases. However recent studies suggest that not all Th17 cells are pathogenic and the local cytokine milieu instead determine their faith ${ }^{[22]}$.

T-helper 22 cells are characterized by their production of 
IL-22 [23]. Interleukin-22 functions in synergy with for example IL-17 but also with TNF- $\alpha$ and IFN- $\gamma{ }^{[24]}$. T-helper 22 cells differentiate in response to TNF- $\alpha$ and IL-6 ${ }^{[23]}$ and effects via the IL-22-IL22R complex ${ }^{[25]}$. These Th22 cells are suggested to play for example an important role in autoimmune diseases like graft versus host disease, rheumatoid arthritis, hepatitis and psoriasis ${ }^{[25]}$ as well as in allergy and epidermial immunity and remodeling ${ }^{[26] .}$

T-cytotoxic cells are important effector cells of the immune system. By destroying cells that express foreign antigens on their surface through major histocompatibility complex (MHC) class I molecules they protect against viral infections and also against certain cancers. Overall, virus-specific $\mathrm{CD}^{+} \mathrm{T}$ cells produce a similar range of cytokines for example IL-2, TNF- $\alpha$, GM-CSF and IFN- $\gamma$ and chemokines for example CCL3, CCL4 and CCL5 as CD4 ${ }^{+}$ T-cells. This indicates that also cytotoxic $\mathrm{T}$ cells can be divided into subpopulations and can obtain cytokine secreting phenotypes that require transcription factors suchlike those of helper $\mathrm{T}$ cells ${ }^{[27]}$. Thus, $\mathrm{Tc} 1$ cells secrete for example IFN- $\gamma{ }^{[28]}$ and naïve $\mathrm{CD}^{+} \mathrm{T}$ cells can be differentiated into Tc17 cells by the same conditions as for Th17 polarizing ${ }^{[29]}$. Furthermore, IL-21 and IL-23 can stimulate activation of Tc22 cells producing IL-22 ${ }^{[24]}$.

Notably, the same cytokine might suppress autoimmune and inflammatory processes resulting in a benign immunological process or alternatively, under different conditions, induce inflammation or autoimmunity.

\section{T-regulatory cells}

T-regulatory (Treg) cells are suggested to maintain self-tolerance of the immune system and have immune suppressive functions for example by inducing protection against viral, bacterial, and parasite antigens in vivo ${ }^{[30,31]}$. Among humans, approximately $1-2 \%$ of the CD4 T cells with high expressing of CD25 (CD4CD25 hi) are found not to proliferate but instead inhibit proliferation and cytokine secretion by activated CD4CD25 responder T cells ${ }^{[32]}$. Thus, lymphocytes with regulatory function are important components of the peripheral tolerance.

Forkhead box P3 (FoxP3) is a member of the forkhead transcription factor family that plays a critical role in the maintenance and function of peripheral $\mathrm{T}$ cells ${ }^{[33]}$. Ectopic expression of the transcription factor FoxP3 can confer a suppressor phenotype to naïve CD4 T-cells ${ }^{[34]}$. Cytotoxic T-lymphocyte associated protein 4 (CTLA-4) is also a useful marker of activated CD4CD25 Treg cells with immune regulatory functions. An abnormal CTLA-4 expression is suggested to result in fatal lymphoproliferative disease.
Interaction of CD80 and/or CD86 with CTLA-4 on activated $\mathrm{T}$ cells inhibit the down-regulatory effect of CTLA-4 on effector cells, thus raise the threshold that is required for CD4CD25 mediated suppression $[30,31]$. The previous described Th3 cells secreting TGF- $\beta$ as well as Tr1 cells secreting IL-4 are other types of Treg cells ${ }^{[30,31]}$. In contrast to CD4CD25, these cells are developed in the periphery and depend on cytokines for suppression.

The principal function of thymus-derived, natural CD4CD25 cells is to prevent autoimmunity. Besides their cytokine-independent but contact-dependent mechanisms of action, they can also induce other CD4 $\mathrm{T}$ cells to become suppressor cells. However, only few natural CD4CD25 cells circulate in human peripheral blood. Adoptive transfer of TGF- $\beta$ and IL-2 ex vivo generated CD4 T-reg cells is suggested to be a potential treatment of autoimmune diseases because these Treg cells have the functional and phenotypic properties including suppressive activity similar to natural occurring CD4CD25 cells ${ }^{[35]}$.

A CD4CD25 hi population expressing the FoxP3 is commonly used for characterization of Treg cells ${ }^{[32,36]}$. In addition, CD101, expressed on for example activated $\mathrm{T}$ cells ${ }^{[37]}$, has shown highly associated with both in vitro and in vivo suppressor activity within $\mathrm{CD} 4{ }^{+} \mathrm{CD} 25^{+}$Treg cells ${ }^{[38]}$. Also the ectonucleotidase CD39, involved in suppression of inflammation, have shown to be expressed on FoxP $3^{+}$Treg cells ${ }^{[39]}$, named $\mathrm{CD} 39^{+} \mathrm{FoxP} 3^{+}$Tregs ${ }^{[40]}$. The IL-9 receptor, CD129 expressed on T cells, together with secreted IL-9 are critical for the early stages of human intrathymic $\mathrm{T}$ cell development to increase the suppressive function of Tregs and is thereby probably of importance for regulation [41]. Contrary, as activated Treg cells express low levels of CD45RA and CD127 both these clusters of differentiation can be used to distinguish different types of Treg cells ${ }^{[42,43]}$.

However, characterization of the true human Treg cell is still not conclusive. This far, $\mathrm{CD} 4{ }^{+} \mathrm{CD} 25^{\text {hi }}$ cells with high expression of CD39, CD101, CD129 and FoxP3 but low expression of CD45RA and CD127 may be the best way for characterization of human Treg cells.

\section{Common autoimmune diseases in children}

In autoimmune disease, the adaptive immune system mistakenly begins attacking specific healthy cells and tissues in almost any part of the body, though often target connective tissues (skin, muscle and joints) — and fails to shut off the attack. Autoimmune diseases in children are generally rare, and when they occur they can be challenging to diagnose, due to for example nonspecific symptoms, and thereafter also difficult to treat. Two of the most common 
diseases with autoimmune characteristic in children are type 1 diabetes (T1D) and celiac disease.

\section{Type 1 diabetes}

Type 1 diabetes is a disease, in genetically predisposed individuals, known to be caused by destruction of the pancreatic $\beta$ cells by an autoimmune origin ${ }^{[44]}$. The autoimmune process can exist for months or even up to years in a so-called preclinical phase \{Castano, $1990 \# 244$ \}. Classic manifestation of the disease includes ketosis and hyperglycemia that occurs due to loss of insulin-producing $\beta$ cells ${ }^{[44]}$.

The infiltrating cells in insulitis lesions include both CD4 ${ }^{+}$ and $\mathrm{CD}^{+} \mathrm{T}$ cells as well as macrophages. In non-obese diabetic (NOD) mice, diabetes has shown to be transferable by $\mathrm{CD} 4^{+}$T-cells expressing a Th1-like cytokine profile ${ }^{[45]}$. Contrary, only few studies have been able to study the disease in vivo due to the fact that the pancreas is located close to several vital organs. Cytotoxic actions of IFN- $\alpha^{[46]}$ and IFN- $\gamma^{[47]}$ have previously been observed on human islets in vivo of patients with recent-onset T1D. It was recently observed that IFN- $\alpha,-\beta$ and $-\gamma$ as well as IL-18 and CXC chemokine ligand 10 (CXCL10) were found in both $\alpha$ and $\beta$ cells in autopsied patients, who died from diabetic ketoacidosis within 2-5 days after onset of fulminant T1D ${ }^{[48,}$ 49]. It was also recently shown that enterovirus infection induced pro-inflammatory cytokine genes of TNF- $\alpha$, IL- $1 \alpha$ and IL-1 $\beta$ from isolated human pancreatic islets ${ }^{[50]}$.

Recently, an attempt to collect pancreatic resection biopsies from living newly onset T1D patients resulted in an unexpectedly high complication rate ${ }^{[51]}$. In this rare in vivo study of human pancreas, mean glucose-stimulated insulin secretion was reduced in islets from T1D patients ${ }^{[52]}$. Also the genes involved in production and release of insulin as well as genes involved in secretion of insulin for example the insulin gene INS were less expressed in patients than in controls ${ }^{[52]}$.

Instead, the majority of immunological studies of T1D are on the peripheral immune system of patients with recent onset T1D. Several studies have indicated a fluctuation in the balance between Th1 and Th2 cells. Studies of the peripheral immune system has shown significantly increased levels of for example IFN- $\gamma$, TNF- $\alpha$, IL-1 $\beta$, and IL-2 in newly diagnosed T1D patients ${ }^{[53,54]}$. It is suggested that the insulitis lesion is $\beta$ cell destructive when IFN- $\gamma$, TNF- $\alpha$ and IL-2 (Th1-like cytokines), produced by islet-infiltrating lymphocytes, dominate over IL-4 (Th2-like cytokine) ${ }^{[55]}$. Contrary, if Th2-type cytokines dominate and downregulate Th1-type cytokine production this may prevent $\beta$ cell destruction in NOD mice as well as in humans ${ }^{[56]}$. An increased cellular response, especially by Th1 cytokines, to the autoantigens insulin [57], glutamic acid decarboxylase $\left(\mathrm{GAD}_{65}\right)^{[58]}$ and tyrosinephosphatase (IA-2) ${ }^{[59]}$ has been found in T1D patients. Our research group has however previously reported a dominant Th1-associated immune profile during the pre-diabetic phase ${ }^{[60-62]}$. At the onset of disease, this Th1 dominance is instead downregulated in favor of a temporary increase of an inflammatory immune profile (TNF- $\alpha$, IL- 6 and the chemokines CCL2 and CXCL9 (monokine upregulated by IFN- $\gamma$ (MIG)) together with increase of a Th3/Tr1-immune profile (TGF- $\beta$ and IL-10), spontaneously as well as by $\mathrm{GAD}_{65}$ stimulation ${ }^{[63,64]}$.

Besides activation of Th1 cells, autoimmune diseases are thought to have also a Th17/Th22 bias. However, the role of Th17/Th22 cells for progression to T1D is still unclear. In vivo activated monocytes from T1D subjects are shown to induce more IL-17-secreting cells from memory $\mathrm{T}$ cells compared with monocytes from healthy controls [65]. An upregulation of Th17 immunity in peripheral blood T cells from children with T1D has also been shown by increased IL-17 secretion and expression of IL-17 and IL-22 [66]. Interleukin-17 and IL-22 overlap in several aspects regarding both biological function and structure and IL-23 is furthermore essential for human Th17 differentiation. The observed increased percentages of both Th17 and Th22, especially during the early stages of T1D $(<5$ years $)$, may indicate the contribution of these Th cell subsets in the pathogenesis of T1D ${ }^{[67]}$.

Studies into the specificity of infiltrating $\mathrm{CD} 8^{+} \mathrm{T}$ cells in the $\beta$ cell lesion are still in an early phase. So far, it has been shown that $\mathrm{CD}^{+} \mathrm{T}$ cells take a center role in the destructive process that contribute to sustained islet inflammation leading to a gradual decrease in $\beta$ cell mass ${ }^{[68]}$. Due to the limited possibility to study human pancreas most studies are performed in the NOD mice model. B cells, high fraction of macrophages and especially $\mathrm{CD}^{+} \mathrm{T}$ cells have been observed in pancreas from human as well as from NOD mice ${ }^{[69]}$. Recent observations indicate for example elevated Tc1 $\left(\mathrm{IFN} \gamma^{+} \mathrm{IL}-17^{-}\right)$and $\mathrm{Tc} 17\left(\mathrm{IL}-17^{+}\right)$cells in patients with T1D $[67,69]$.

The role of Treg cells i.e. changes in expression and function for the development of human T1D is still not clearly elucidated ${ }^{[70]}$. Expression of $\mathrm{CD} 25$ on $\mathrm{CD} 4^{+} \mathrm{T}$ cells is found to be normally expressed in patients with T1D [71]. Despite the observed ability to express high amounts of CD25 on CD4 (CD4CD25 hi) the capacity of Treg cells to suppress $\mathrm{T}$ cell proliferation during in vitro co-cultures with anti-CD3 antibodies is markedly reduced in T1D patients ${ }^{[71]}$. Defect in regulation of Treg cells seems to result in increased 
secretion of IFN- $\gamma$ together with decreased release of IL-10 [71]. In NOD mice model, it has been observed that retroviral transduction of polyclonal CD4 T cells with FoxP3 is not effective in interfering with established T1D [72]. Interestingly, it has been found that Foxp3/scurfin gene is located on chromosome Xp11.23, which includes one of the T1D susceptibility loci ${ }^{[73]}$. Tumor necrosis factor- $\beta$ is found at high levels at inflammatory sites playing an essential role for the generation of $\mathrm{FoxP}_{3}{ }^{+}$inducible Treg cells as well as an important effect on natural Treg cells [74, 75]. Also increased IL-10 secretion has been observed in longstanding T1D patients (6 months to 5 years after diagnosis) ${ }^{[76]}$ However, even if the Th3/Tr1 response is found to be high at onset of T1D, an immune regulatory defect by reduced function of Treg cells has been observed ${ }^{[71]}$.

We have previously shown a significantly lower percentages of $\mathrm{CD} 4^{+} \mathrm{CD} 25^{+} \mathrm{CD} 127^{\mathrm{lo} /}$ among $\mathrm{CD} 4^{+} \mathrm{T}$ cells and lower $\mathrm{CD} 4{ }^{+} \mathrm{CD} 25^{+} \mathrm{CD} 127^{\text {lo/- }}$ to $\mathrm{CD} 4{ }^{+} \mathrm{CD} 25^{-}$cell ratio in T1D children compared to healthy individuals ${ }^{[77]}$. Recently, we also found low expression of $\mathrm{CD}^{2} 9^{+}$and $\mathrm{CD} 45 \mathrm{RA}^{+}$on $\mathrm{CD} 4{ }^{+} \mathrm{CD} 25^{+} \mathrm{FoxP} 3{ }^{+} \mathrm{CD} 127^{-} \mathrm{T}$ reg cells in T1D children that may indicate loss of suppressive function ${ }^{[78]}$. Defective regulation is suggested as a feature of T1D regardless of disease duration and an impaired ability of responder $\mathrm{T}$ cells to be suppressed contributes to this defect [79]. However, there is still no precise definition of human Treg cells even though lower expression of CD127 is a good complement to expression of CD4 and CD25 [42]. Furthermore, nearly all studies on the importance of Tregs for the development of T1D are performed on peripheral blood, suggesting that $\mathrm{T}$ cell populations in the periphery reflect the immune activity at site i.e. pancreas ${ }^{[70]}$. This may explain the divergent results from studies on the suppressive function of Treg cells indicating either normal ${ }^{[42,80]}$, decreased ${ }^{[81,82]}$ or increased ${ }^{[83]}$ suppressive function in the pathogenesis of T1D. It is suggested that once autoimmunity is triggered, the progressive decrease in $\beta$ cell function may be caused by subsequent exposure events ${ }^{[84]}$. Unfortunately, many trials fail to demonstrate clinical response even when Treg treatment successfully boosts Tregs ${ }^{[70]}$. Actually, it has been indicated that the effector $\mathrm{T}$ cell population can resist the activity of Treg cells in patients with T1D ${ }^{[79,80]}$.

\section{Celiac disease}

Celiac disease is considered a multi-factorial autoimmune-like disease, triggered by the ingestion of gluten in genetically susceptible subjects [85], with an increasing frequency ${ }^{[86]}$. Besides gluten also tissue transglutaminase (tTG) is suggested as an autoantigen for the development of celiac disease ${ }^{[87]}$. Is has been shown that TTG selectively deamidates gluten peptides, which results in strongly enhanced $\mathrm{T}$ cell stimulatory activity ${ }^{[88]}$.

A cross-reactivity between the immune system and the mucosa is initiated when gluten peptides, which are partly resistant to enzymatic processing, cross the intestinal epithelium leading to an inflammatory reaction, resulting in crypt hyperplasia and villous atrophy. After gluten withdrawal the diseased mucosa heals and autoantibodies disappear.

Within the gluten protein, many different epitopes can activate intestinal $\mathrm{CD}^{+} \mathrm{T}$ cells. A trend towards a superior accumulation of IFN- $\gamma$ in vivo ${ }^{[89]}$ promoting inflammatory effects and a non-proliferative activation of $\mathrm{CD} 4^{+}$lamina propria $\mathrm{T}$ cells, especially by activation of Th1-like cells secreting IFN- $\gamma{ }^{[90]}$ have been shown by gluten. Besides IFN- $\gamma$ also for example IL-2 and TNF- $\beta$ mRNA expression have been observed in biopsies from active celiac patients [91]. In contrast, Th2-associated IL-4 is found equally expressed in

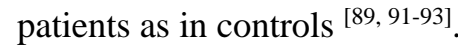

Interferon regulatory factor (IRF) and STAT-1 together with reduced IL-2 expression are also found to be pronounced in small intestinal biopsies from untreated celiac disease in children ${ }^{[94]}$. One year after gluten free diet downregulation of IFN- $\gamma$ mRNA is observed even though the signaling pathway for this interferon still is upregulated [94]. T-regulatory as well as Th17 cells have also recently been shown to be involved in the pathogenesis of untreated celiac disease. In fact, it has been shown that, at baseline, Th1 as well as Th17 and Treg cells are significantly higher in active celiac disease patients observed both in tissue-infiltrating lymphocytes as well as in peripheral blood. Recently, we observed that children with coeliac disease show signs of $\mathrm{CD} 4{ }^{+} \mathrm{CD} 25^{\text {hi }}$ Treg cells expression also CD $101^{+}$and $\mathrm{CD} 129^{+}$ that may indicate suppressor activity ${ }^{[78]}$.

Treatment with a gluten-free diet however influences the immunological pattern and decreases Th1-, Th17 and Treg cells ${ }^{[95]}$. Gluten-free diet has shown to also normalize the expression of Th2 gene markers for example IL-4R, IL-13RA1, IL-5 and STAT6 ${ }^{[94]}$ and the production of IL-10 by intraepithelial lymphocytes ${ }^{[89]}$. Recombinant human IL-10 has even been shown to induce a long term hypo-responsiveness of gliadin specific mucosal T cells ${ }^{[96]}$.

T-regulatory cells are thought to contribute to the immunological failure in celiac disease. In duodenal biopsy samples from patients with an active celiac disease a higher density of $\mathrm{CD}^{+}{ }^{+} \mathrm{CD} 25^{+} \mathrm{FoxP} 3^{+} \mathrm{T}$ cells has been observed in comparison to patients with treated celiac disease and healthy controls ${ }^{[97]}$. In co-culture, these Treg cells are shown to be functionally suppressive, but their activity is impaired by for 
example IL-15 ${ }^{\text {[97] }}$. Contrary, a low grade inflammation has been detected in individuals with potential risk of developing celiac disease who still have a normal small intestinal mucosa but with a positive $\mathrm{CD}$-associated serology ${ }^{[98]}$. Intestinal $\mathrm{CD} 4{ }^{+} \mathrm{CD} 25^{+} \mathrm{T}$ cells with suppressive effects on $\mathrm{T}$ responder cell may however prevent this low grade inflammation ${ }^{[98]}$.

\section{Combination of type 1 diabetes and celiac disease}

Type 1 diabetes and celiac disease are two immune-mediated diseases sharing common susceptibleness factors including for example environment and genetics. In $85-90 \%$ of all cases of these two diseases in combination, T1D is diagnosed before celiac disease and most cases of celiac disease are diagnosed within 5 years of T1D diagnosis [99]. Complications for type 1 diabetic patients with also celiac autoimmunity are higher $\mathrm{HbA1c}$, more hypoglycaemic episodes, higher prevalence of iron and vitamin B12 deficiency, lower insulin-growth factor-1 (IGF-1) and also lower bone mineral density ${ }^{[100]}$.

\section{Prevalence of celiac disease in type 1 diabetic patients}

The overall incidence of both T1D and celiac disease individually is increased ${ }^{[86,101]}$. Comparison with prevalence of coeliac disease in the general population reveals an at least 10 -fold increase in patients with T1D. Patients with manifest T1D may have had a latent celiac disease, which is activated parallel to the anti-islet immune reactivity during the development of T1D. Out of a cohort of approximately 28.000 T1D patients, $10.7 \%$ produced as well tTG autoantibodies ${ }^{[102]}$. A recent systematic review of more than 26.000 T1D patients revealed that one in twenty patients with T1D have biopsy-verified celiac disease, thus a prevalence of $6.0 \%{ }^{[103]}$. Contrary, a low prevalence of $\beta$-cell autoimmunity is found in young patients with celiac disease ${ }^{[104]}$.

\section{Genetics in common for celiac disease and type 1 diabetes}

Celiac disease has an autoimmune characteristic with known HLA (HLA-DQA1 and HLA-DQB1) association ${ }^{[105] .}$ Homozygotic carries of DQB $1 * 02$ have higher risk of developing celiac disease than heterozygote individuals [106] leaving a larger window for additional risk factors outside the HLA haplotypes in heterozygotic individuals. Among T1D, approximately $30-50 \%$ of all patients are heterozygotes for HLA DR3-DQ2 and DR4-DQ8 genotype.

Since the genotype DR3-DQ2 shows as well a strong associations with celiac disease, this indicates a genetic similarity in these two diseases. Thus, both diseases are associated with HLA class II genes on chromosome 6p21 and that can, to some extent, explain the co-segregate of these two diseases in the population. Actually, T1D patients homozygous for DR3-DQ2 carry a 33\% risk for the presence of tTG autoantibodies ${ }^{[107]}$.

Furthermore, a higher permeability has been found in type 1 diabetics with a DQB $1 * 02$ allele that may predispose for an abnormal immune responses against food antigens [108]. Contrary, it was recently suggested that DPB $1 * 04$ may reduce the risk of tTGAs autoantibodies and thus was inversely associated with coeliac disease autoimmunity [109]. Also non-HLA genes for example CTLA-4, tyrosine-protein phosphatase non-receptor type 2 (PTPN2) and CCR5 genes, are pointed out as predicting factors for both T1D and celiac disease ${ }^{[110]}$.

\section{Effect of gluten-free diet}

Among patients with both T1D and celiac disease, the majority of patients are diagnosed with T1D before the diagnosis of celiac disease. It has been a controversy between the suggestion that gluten can be the driving antigen and immunological trigger able to induce T1D in silent, untreated celiac disease ${ }^{[111]}$ or instead, that gluten-free diet can have a diabetes-protective effect ${ }^{[112]}$.

Is has been shown that the pathogenesis of T1D is influenced by diet ${ }^{[113]}$ and that a gluten-free diet reduces the incidence to $6 \%$ in animals model (NOD mice) ${ }^{[114]}$. However, in humans the results are more conflicting. Insulin sensitivity is shown to improve after gluten-free diet in first-degree relatives of T1D patients ${ }^{[15]}$. However, this improvement has not been seen to influence on humoral autoimmunity since autoantibodies do not change during the period of gluten-free diet ${ }^{[115]}$. Likewise, islet autoantibody levels are not changed in islet-antibody-positive first degree relatives of patients with T1D placed on gluten-free diet for 12 months ${ }^{[116]}$. Thus, a gluten-free diet has not been shown able to delay or prevent development of T1D [116, 117]. Likewise, in an intervention study in which infants with high genetic risk for T1D were randomized to either early or late introduction of gluten, no benefit in delaying gluten exposure could be find in respect to celiac disease autoimmunity or T1D up to the age of three years ${ }^{[118]}$. Neither could the same intervention study, at a follow-up at the age of 8 years, indicate that delayed gluten introduction can decrease the risk of developing autoimmune T1D ${ }^{[119]}$. Also, in a 2-year prospectively followed cohort of subjects with already diagnosed T1D, with and without celiac autoimmunity, no significant adverse outcome was found in children with a delayed introduction of gluten ${ }^{[120]}$.

Thus, there is still a controversial regarding the effect of gluten-free diet in T1D patients with celiac disease. At first it 
was suggested that glycemic control in patients with both T1D and celiac disease was improved by gluten-free diet ${ }^{[121]}$. More recent studies instead suggests that a gluten-free diet can lead to increased weight gain and raised body mass index (BMI) due to high saturated fat and high glycemic index carbohydrate ${ }^{[122]}$.

\section{$T$ cell response to gluten and also other dietary antigens}

A limited $\mathrm{T}$ cell response to gluten has been able to detected in newly diagnosed T1D patients ${ }^{[123]}$. It has also been shown that approximately $50 \%$ of tTG autoantibody negative T1D patients display an increased $\mathrm{CD}^{+} \mathrm{T}$ cell proliferation to dietary wheat polypeptides ${ }^{[124]}$. In these T1D patients also a mixed cytokine response of for example TNF, IFN- $\gamma$ and IL-17A were observed whereas the pro-inflammatory secretion was inhibited by anti-DR antibodies ${ }^{[124]}$. The degree of celiac disease in T1D patients has also in another study been correlated to the densities of IFN- $\gamma$ mRNA positive cells as well as IFN- $\gamma$, IL-2 and TNF- $\alpha$-positive cells ${ }^{[125]}$. This may indicate a diabetes-related inflammatory state in the gut immune tissues associated with defective oral tolerance and possibly gut barrier dysfunction [124]. Actually, involvement of gut immune system has been implicated in the pathogenesis of T1D. Increased expression of IL-18 mRNA in the small intestinal biopsies ${ }^{[126]}$ and increased $\alpha 4 / \beta 7$-integrin ${ }^{+}$cells in the lamina propria have been found among T1D patients indicating inflammation ${ }^{[127]}$.

It has also been suggested that newly diagnosed diabetic patients have a non-specific activation of the immune system directed towards several dietary proteins for example bovine serum albumin (BSA) and beta-lactoglobulin ( $\beta \mathrm{LG}$ ), as a result of a defective immune regulation or loss of immunological tolerance to a variety of ingested antigens [128-130]. The same pattern is noted in celiac disease, where antibodies not only to gluten but also to other dietary proteins are elevated before treatment ${ }^{[131]}$.

On the contrary, in children diagnosed with both T1D and coeliac disease, we have previously shown a diminished Th1-like immune profile. Children with combination of these two diseases showed hardly any IFN- $\gamma$ secretion after in vitro stimulation with either gluten or other food agents ( $\beta \mathrm{LG}$ and ovalbumin (OVA)). The same diminished Th1-like profile response was also seen towards for example inhalation allergens (birch and cat extract). This result was very distinct from children diagnosed with either T1D or celiac disease as well as reference children and suggests a suppressed immune response in children with combination of these two diseases [132].

\section{T-regulatory associated immunity}

Gluten as a possible antigen to induce peripheral blood mononuclear cell (PBMC) expression of FoxP3 mRNA to a higher extent in children with celiac disease compared to reference children has for example been shown by our research group ${ }^{[133]}$. Enhanced intestinal expression of FOXP3 mRNA has as well been shown in active celiac disease patients compared to controls ${ }^{[126]}$.

A few percentages of $\mathrm{T}$ cells implicated in insulitits origin from the intestinal. This may explain why signs of mucosal inflammation by increased density of lamina propria $\mathrm{CD} 25^{+}$ mononuclear cells and intraepithelial $\mathrm{CD}^{+}$cells in jejunal biopsies as well as increased $\mathrm{CD} 25^{+}$mononuclear cells in biopsies exposed to gladin has been observed in small intestinal biopsies from T1D children ${ }^{[134]}$.

In children diagnosed with both T1D and celiac disease, we have been able to show an increased peripheral expression of phytohaemagglutinin (PHA)-induced FoxP3 mRNA in comparison to children diagnosed exclusively with T1D ${ }^{[133]}$. Increased frequency of $\mathrm{CD} 4{ }^{+} \mathrm{CD} 25^{+} \mathrm{FoxP} 3^{+}$cells together with pronounced expression of FoxP3 mRNA have also been detected in small-bowel biopsy specimens from children diagnosed with both celiac disease and T1D ${ }^{[126,135]}$. Further, the density of $\mathrm{FoxP}^{+}$cells are also correlate with histological grade of atrophic changes in the small bowel [136]. Upregulated FoxP3 expression may counterbalance the loss of mucosal integrity by maintaining immune tolerance in the small intestine of patient with both celiac disease and T1D [137]. Contrary, a low expression of the tight junction protein 1 (TJP1) serving as a marker of intestinal mucosa integrity has been found in patients with both T1D and celiac disease ${ }^{[136,138]}$. Also gliadin and tTG IgA antibodies were the highest in these patients ${ }^{[138]}$. These results may reveal that intestinal permeability is most severely impaired in patients with these two immunological diseases in combination ${ }^{[138]}$.

\section{Combination of type 1 diabetes and celiac disease - an immunological challenge}

We have recently shown that children suffering from both type 1 diabetes and celiac disease show higher percentage of terminally differentiated effector cells (TEMRA) $\mathrm{CD} 4^{+}$cells in contrast to a lower percentages of both early and late effector memory $\mathrm{CD}^{+}$cells compared to references ${ }^{[78]}$. Previous observation of pancreatic grafts show that a large population of $\mathrm{CD} 8^{+}$pancreas-infiltrating lymphocytes lacks expression of CD28 ${ }^{[139]}$. Immune aberrancies have also been shown in the gut, in children who are prone to T1D, suggesting poor development of oral tolerance ${ }^{[125]}$. This may 
reduce the immunological process towards proteins/antigen in general. This is a theory supported by our previous observation that children suffering from these two immunological diseases in combination show a suppressed immune response (IFN- $\gamma$ ) to both food (gluten, milk and egg) and inhalant antigens (birch and cat extract) compared to children with either T1D or celiac disease as well as compared to reference children ${ }^{[132]}$.

These results as well as the previous presented data indicate that the combination of type 1 diabetes and celiac disease is an immunological challenge and it is obvious that we are far from understanding the immunological impact of these two autoimmune diseases in combination. This immunological challenge needs to be elucidated to be able to predict and prevent these common autoimmune diseases.

\section{Conflicting interests}

The author has declared that no competing interests exist.

\section{Abbreviations}

$\beta$ LG: beta-lactoglobulin; BSA: bovine serum albumin; BMI: body mass index; CCL: C-C motif ligand; CCR: C-C motif receptor; $\mathrm{CD}$ : cluster of differentiation; CTLA: cytotoxic T lymphocyte associated protein; CXC: C-X-C motif ligand; GAD: glutamic acid decarboxylase; GM-CSF: granulocyte macrophage colony-stimulating factor; FoxP3: forkhead box P3; IA-2: tyrosine phosphatase; IFN: interferon; IGF: insulin growth factor; IL: interleukin; IP-10: IFN- $\gamma$ -inducible protein 10; IRF: interferon response factor; MCP: monocyte chemoattractant protein; MHC: major histocompatibility complex; MIG: monokine upregulated by IFN- $\gamma$; MIP: macrophage inflammatory protein; NK: natural killer; NOD: non-obese diabetic; OVA: ovalbumin; PBMC: peripheral blood mononuclear cell; PHA: phytohaemagglutinin; PTPN2: tyrosine-protein phosphatase non-receptor type 2; RANTES: regulated on activation, normal T cell expressed and secreted; ROR-C: RAR-related orphan receptor; STAT: signal transducer and activator of transcription; T1D: type 1 diabetes; T-bet: T-box expressed in $\mathrm{T}$ cells; $\mathrm{Tc}$ : T-cytotoxic; TEMRA: terminally differentiated effector cells; TGF: transforming growth factor; Th: T-helper; TJP: tight junction protein; TNF: tumor necrosis factor; Treg: T-regulatory; tTG: tissue transglutaminase.

\section{References}

1. Romero P, Zippelius A, Kurth I, Pittet MJ, Touvrey C, Iancu EM, et al. Four functionally distinct populations of human effector-memory CD8+ T lymphocytes. J Immunol 2007; 178:4112-4119.
2. Mosmann TR, Cherwinski H, Bond MW, Giedlin MA, Coffman RL. Two types of murine helper $T$ cell clone. I. Definition according to profiles of lymphokine activities and secreted proteins. J Immunol 1986; 136:2348-2357.

3. Jacobson NG, Szabo SJ, Weber-Nordt RM, Zhong Z, Schreiber $\mathrm{RD}$, Darnell JE, et al. Interleukin 12 signaling in $\mathrm{T}$ helper type 1 (Th1) cells involves tyrosine phosphorylation of signal transducer and activator of transcription (Stat)3 and Stat4. J Exp Med 1995; 181:1755-1762.

4. Szabo SJ, Kim ST, Costa GL, Zhang X, Fathman CG, Glimcher LH. A novel transcription factor, T-bet, directs Th1 lineage commitment. Cell 2000; 100:655-669.

5. Kurowska-Stolarska M, Kewin P, Murphy G, Russo RC, Stolarski $\mathrm{B}$, Garcia CC, et al. IL-33 induces antigen-specific IL-5+ T cells and promotes allergic-induced airway inflammation independent of IL-4. J Immunol 2008; 181:4780-4790.

6. Fallon PG, Jolin HE, Smith P, Emson CL, Townsend MJ, Fallon R, et al. IL-4 induces characteristic Th2 responses even in the combined absence of IL-5, IL-9, and IL-13. Immunity 2002; 17:7-17.

7. Sallusto F, Lanzavecchia A, Mackay CR. Chemokines and chemokine receptors in T-cell priming and Th1/Th2-mediated responses. Immunol Today 1998; 19:568-574.

8. Bradley LM, Asensio VC, Schioetz LK, Harbertson J, Krahl T, Patstone G, et al. Islet-specific Th1, but not Th2, cells secrete multiple chemokines and promote rapid induction of autoimmune diabetes. J Immunol 1999; 162:2511-2520.

9. Schrum S, Probst P, Fleischer B, Zipfel PF. Synthesis of the CC-Chemokine MIP-1 $\alpha$, MIP-1 $\beta$, and RANTES is asociated with a type 1 immune response. J Immunol 1996; 157:3598-3604.

10. Weiner HL. Induction and mechanism of action of transforming growth factor-beta-secreting Th3 regulatory cells. Immunol Rev 2001; 182:207-214.

11. Schmitt E, Beuscher HU, Huels C, Monteyne P, van Brandwijk R, van Snick J, et al. IL-1 serves as a secondary signal for IL-9 expression. J Immunol 1991; 147:3848-3854.

12. Schmitt E, Germann T, Goedert S, Hoehn P, Huels C, Koelsch S, et al. IL-9 production of naive CD4+ T cells depends on IL-2, is synergistically enhanced by a combination of TGF-beta and IL-4, and is inhibited by IFN-gamma. J Immunol 1994; 153:3989-3996.

13. Ramming A, Druzd D, Leipe J, Schulze-Koops H, Skapenko A. Maturation-related histone modifications in the PU.1 promoter regulate Th9-cell development. Blood 2012; 119:4665-4674.

14. Jager A, Dardalhon V, Sobel RA, Bettelli E, Kuchroo VK. Th1, Th17, and Th9 effector cells induce experimental autoimmune encephalomyelitis with different pathological phenotypes. J Immunol 2009; 183:7169-7177.

15. Kaplan MH, Glosson NL, Stritesky GL, Yeh N, Kinzfogl J, Rohrabaugh SL, Goswami R, et al. STAT3-dependent IL-21 production from $\mathrm{T}$ helper cells regulates hematopoietic progenitor cell homeostasis. Blood 2011; 117:6198-6201.

16. Stassen M, Schmitt E, Bopp T. From interleukin-9 to T helper 9 cells. Ann N Y Acad Sci 2012; 1247:56-68.

17. Purwar R, Schlapbach C, Xiao S, Kang HS, Elyaman W, Jiang X, et al. Robust tumor immunity to melanoma mediated by interleukin-9-producing T cells. Nat Med 2012; 18:1248-1253. 
18. Nowak EC, Weaver CT, Turner H, Begum-Haque S, Becher B, Schreiner B, et al. IL-9 as a mediator of Th17-driven inflammatory disease. J Exp Med 2009; 206:1653-1660.

19. Park H, Li Z, Yang XO, Chang SH, Nurieva R, Wang YH, et al. A distinct lineage of CD4 $\mathrm{T}$ cells regulates tissue inflammation by producing interleukin 17. Nat Immunol 2005; 6:1133-1141.

20. Harrington LE, Hatton RD, Mangan PR, Turner H, Murphy TL, Murphy KM, et al. Interleukin 17-producing CD4+ effector T cells develop via a lineage distinct from the T helper type 1 and 2 lineages. Nat Immunol 2005; 6:1123-1132.

21. Langrish CL. IL-23 drives a pathogenic $\mathrm{T}$ cell population that induces autoimmune inflammation. J Exp Med 2005; 201: 233-240.

22. Kumar P, Subramaniyam G. Molecular underpinnings of Th17 immune-regulation and their implications in autoimmune diabetes. Cytokine 2015; 71:366-376.

23. Nograles KE, Zaba LC, Shemer A, Fuentes-Duculan J, Cardinale I, Kikuchi T, et al. IL-22-producing "T22" $\mathrm{T}$ cells account for upregulated IL-22 in atopic dermatitis despite reduced IL-17-producing TH17 T cells. J Allergy Clin Immunol 2009; 123:1244-1252.e1242.

24. Rutz S, Eidenschenk C, Ouyang W. IL-22, not simply a Th17 cytokine. Immunol Rev 2013; 252:116-132.

25. Yang X, Zheng SG. Interleukin-22: a likely target for treatment of autoimmune diseases. Autoimmun Rev 2014; 13:615-620.

26. Eyerich S, Eyerich K, Pennino D, Carbone T, Nasorri F, Pallotta S, et al. Th2 2 cells represent a distinct human T cell subset involved in epidermal immunity and remodeling. J Clin Invest 2009; 119:3573-3585.

27. Shrikant PA. Regulating functional cell fates in CD8 T cells. Immunol Res 2010; 46:12-22.

28. Ye Z. Type $1 \mathrm{CD} 8+\mathrm{T}$ cells are superior to type $2 \mathrm{CD} 8+\mathrm{T}$ cells in tumor immunotherapy due to their efficient cytotoxicity, prolonged survival and type 1 immune modulation. Cell Mol Immunol 2007; 4:277-285.

29. Hinrichs CS. Type 17 CD8+ T cells display enhanced antitumor immunity. Blood 2009; 114:596-599.

30. McGuirk P, Mills KHG. Pathogen-specific regulatory T cells provoke a shift in the Th1/Th2 paradigm in immunity to infectious diseases. Trends in Immunol 2002; 23:450-455.

31. Wildbaum G, Netzer N, Karin N. Tr1-cell-dependent active tolerance blunts the pathogenic effects of determinant spreading. $\mathrm{J}$ Clin Invest 2002; 110:701-710.

32. Baecher-Allan C, Brown JA, Freeman GJ, Hafler DA. $\mathrm{CD} 4+\mathrm{CD} 25$ high regulatory cells in human peripheral blood. J Immunol 2001; 167:1245-1253.

33. Schubert LA, Jeffrey E, Zhang Y, Ransdell F, Ziegler SF. Scurfin (FOXP3) acts as a repressor of transcription and regulates T-cell activation. J Biol Chem 2001; 276:37672-37679.

34. Hori S, Nomura T, Sakaguchi S. Control of regulatory $\mathrm{T}$ cell development by the transcription factor Foxp3. Science 2003; 299:1057-1061.

35. Horwitz DA, Zheng SG, Gray JD, Wang JH, Ohtsuka K, Yamagiwa S. Regulatory T cells generated ex vivo as an approach for the therapy of autoimmune disease. Sem Immunol 2004;
$16: 135-143$.

36. Walker MR, Kasprowicz DJ, Gersuk VH, Benard A, Van Landeghen $\mathrm{M}$, Buckner $\mathrm{JH}$, et al. Induction of Foxp3 and acqustion of $\mathrm{T}$ regulaotry activity by stimulated human CD4+CD25- T cells. J Clin Invest 2003; 112:1437-1443.

37. Rivas A, Ruegg CL, Zeitung J, Laus R, Warnke R, Benike C, et al. $\mathrm{V} 7$, a novel leukocytes surface protein that participates in $\mathrm{T}$ cell activation. J Immunol 1995; 154:4423-4433.

38. Fernandez I, Zeiser R, Karsunky H, Kambham N, Beilhack A, Soderstrom K, et al. CD101 surface expression discriminates potency among murine FoxP3+ regulatory $\mathrm{T}$ cells. J Immunol 2007; 179:2808-2814.

39. Deaglio S, Dwyer KM, Gao W, Friedman D, Usheva A, Erat A, et al. Adenosine generation catalysed by CD39 and CD73 expressed on regulatory $\mathrm{T}$ cells mediates immune suppression. J Exp Med 2007; 204:1257-1265.

40. Tang Y, Jiang L, Zheng Y, Ni B, Wu Y. Expression of CD39 on FoxP3 $+\mathrm{T}$ regulatory cells correlates with pregression of $\mathrm{HBV}$ infection. BMC Immunol 2012; 13:17.

41. De Smedt M, Verhasselt B, Kerre T, Vanhecke D, Naessens E, Leclercq G, et al. Signals from the IL-9 receptor are critical for the early stages of human intrathymic T cell development. J Immunol 2000; 164:1761-1767.

42. Liu W, Putnam AL, Xu-yu Z, Szot GL, Lee MR, Zhu S, et al. CD127 expression inversely correlates with FOXP3 and suppressive function of human CD4+ T reg cells. J Exp Med 2006; 203:1701-1711.

43. Miyara M, Yoshioka Y, Kitoh A, Shima T, Wing K, Niwa A, et al. Functional delineation and differentiation dynamics of human CD4+ T cells expression the FoxP3 transcription factor. Immunity 2009; 30:899-911.

44. Castano L, Eisenbarth GS. Type-I diabetes: A chronic autoimmune disease of human, mouse, and rat. Annu Rev Immunol 1990; 8:647-679.

45. Katz JD, Benoist C, Mathis D. $\mathrm{T}$ helper cell subsets in insulin-dependent diabetes. Science 1995; 268:1185-1188.

46. Somoza N, Vargas F, Roura-Mir C, Vives-Pi M, Fernandez-Figueras MT, Ariza A, et al. Pancreas in recent onset insulin-dependent diabetes mellitus: Changes in HLA, adhesion molecules and autoantigens, restricted $\mathrm{T}$ cell receptor $\mathrm{Vb}$ usage, and cytokine profile. J Immunol 1994; 153:1360-1377.

47. Foulis AK, McGill M, Farquharson MA. Insulitis in type 1 (insulin-dependent) diabetes mellitus in man - macrophages, lymphocytes, and interferon-g containing cells. J Pathol 1991; 165:97-103.

48. Tanaka S, Nishida Y, Aida K, Maruyama T, Shimada A, Suzuki $\mathrm{M}$, et al. Enterovirus infection, CXC chemokine ligand 10 (CXCL10), and CXCR3 circuit: a mechanism of accelerated beta-cell failure in fulminant type 1 diabetes. Diabetes 2009; 58:2285-2291.

49. Aida K, Nishida Y, Tanaka S, Maruyama T, Shimada A, Awata T, et al. RIG-I- and MDA5-initiated innate immunity linked with adaptive immunity accelerates beta-cell death in fulminant type 1 diabetes. Diabetes 2011; 60:884-889.

50. Ylipaasto P, Smura T, Gopalacharyulu P, Paananen A, Seppanen-Laakso T, Kaijalainen S, et al. Enterovirus-induced 
gene expression profile is critical for human pancreatic islet destruction. Diabetologia 2012; 55:3273-3283.

51. Krogvold L, Edwin B, Buanes T, Ludvigsson J, Korsgren O, Hyoty $\mathrm{H}$, et al. Pancreatic biopsy by minimal tail resection in live adult patients at the onset of type 1 diabetes: experiences from the DiViD study. Diabetologia 2014; 57:841-843.

52. Krogvold L, Skog O, Sundstrom G, Edwin B, Buanes T, Hanssen $\mathrm{KF}$, et al. Function of isolated pancreatic islets from patients at onset of type 1 diabetes; Insulin secretion can be restored after some days in a non-diabetogenic environment in vitro. Results from the DiViD study. Diabetes 2015; 64:2506-2512.

53. Hussain MJ, Peakman M, Gallati H, Lo SSS, Hawa M, Viberti GC, et al. Elevated serum levels of macrophage-derived cytokines precede and accompany the onset of IDDM. Diabetologia 1996; 39:60-69.

54. Kallmann BA, Hüther M, Tubes M, Feldkamp J, Bertrams J, Gries $\mathrm{FA}$, et al. Systemic bias of cytokine production toward cell-mediated immune regulation in IDDM and toward humoral immunity in Graves'disease. Diabetes 1997; 46:237-243.

55. Christen U, von Herrath MG. Manipulating the type 1 vs type 2 balance in type 1 diabetes. Immunol Res 2004; 30:309-325.

56. Rabinovitch A. Immunoregulatory and cytokine imbalances in the pathogenesis of IDDM. Therapeutic intervention by immunostimulation? Diabetes 1994; 43:613-621.

57. Keller RJ. Cellular immunity to human insulin in individuals at high risk for the development of type 1 diabetes mellitus. J Autoimmun 1990; 3:321-327.

58. Atkinson MA, Kaufman DL, Campbell L, Gibbs KA, Shah SC, Bu D-F, et al. Response of peripheral-blood mononuclear cells to glutamate decarboxylase in insulin-dependent diabetes. Lancet $1992 ; 339: 458-459$.

59. Ellis TM, Schatz DA, Ottendorfer EW, Lan MS, Wasserfall C, Salisbury PJ, et al. The relationship between humoral and cellular immunity to IA-2 in IDDM. Diabetes 1998; 47:566-569.

60. Karlsson MGE, Sederholm Lawesson S, Ludvigsson J. Th1-like dominance in high-risk first-degree relatives of type 1 diabetic patients. Diabetologia 2000; 43:742-749.

61. Hedman M, Ludvigsson J, Karlsson Faresjö MGE. Nicotinamide reduces high secretion of IFN-g in high-risk relatives even though it does not prevent type 1 diabetes. J Interferon Cytokine Res 2006; 26:207-213.

62. Stechova K, Bohmova K, Vrabelova Z, Sepa A, Stadlerova G, Zacharovova $\mathrm{K}$, et al. High T-helper-1 cytokines but low T-helper-3 cytokines, inflammatory cytokines and chemokines in children with high risk of developing type 1 diabetes. Diabetes Metab Res Rev 2007; 23:462-471.

63. Karlsson Faresjö M, Vaarala O, Thuswaldner S, Ilonen J, Hinkkanen A, Ludvigsson J. Diminished IFN- $\gamma$ response to disease-associated autoantigens in children at diagnosis and during follow up of type 1 diabetes. Diabetes/Metabolism Research and Reviews 2006; 22:462-470.

64. Ryden A, Stechova K, Durilova M, Faresjö M. Switch from a dominant Th1-associated immune profile during the pre-diabetic phase in favour of a temporary increase of a Th3-associated and inflammatory immune profile at the onset of type 1 diabetes. Diabetes Metab Res Rev 2009; 25:335-343.
65. Bradshaw EM, Raddassi K, Elyaman W, Orban T, Gottlieb PA, Kent SC, et al. Monocytes from patients with type 1 diabetes spontaneously secrete proinflammatory cytokines inducing Th17 cells. J Immunol 2009; 183:4432-4439.

66. Honkanen J, Nieminen JK, Gao R, Luopajarvi K, Salo HM, Ilonen $\mathrm{J}$, et al. IL-17 immunity in human type 1 diabetes. J Immunol 2010; 185:1959-1967.

67. Xu X, Zheng S, Yang F, Shi Y, Gu Y, Chen H, et al. Increased Th22 cells are independently associated with Th17 cells in type 1 diabetes. Endocrine 2014; 46:90-98.

68. Tsai S, Shameli A, Santamaria P. CD8+ T cells in type 1 diabetes. Advances in immunology 2008; 100:79-124.

69. In't Veld P. Insulitis in human type 1 diabetes: a comparison between patients and animal models. Semin Immunopathol 2014; 36:569-579.

70. Tan T, Xiang Y, Chang C, Zhou Z. Alteration of regulatory T cells in type 1 diabetes mellitus: a comprehensive review. Clin Rev Allergy Immunol 2014; 47:234-243.

71. Lindley S, Dayan CM, Bishop A, Roep BO, Peakman M, Tree TIM. Defective suppressor function in CD4+CD25+ T-cells from patients with type 1 diabetes. Diabetes 2005; 54:92-99.

72. Jaeckel E, von Boehmer H, P. MM. Antigen-specific FoxP3-transduced T-cells can control established type 1 diabetes. Diabetes 2005; 54:306-310.

73. Cucca F, Goy JV, Kawaguchi Y, Esposito L, Merriman ME, Wilson AJ, et al. A male-female bias in type 1 diabetes and linkage to chromosome Xp in MHC HLA-DR3-positive patinets. Nat Genet 1998; 19:301-302.

74. Rubtsov YP, Rudensky AY. TGF $\beta$ signalling in control of T-cell-mediated self-reactivity. Nat Rev Immunol 2007; 7:443-453.

75. Tran DQ, Ramsey H, Shevach EM. Induction of FOXP3 exprssion in naive human $\mathrm{CD} 4+\mathrm{FOXP} 3-\mathrm{T}$ cells by $\mathrm{T}$-cell receptor stimulation is transforming growth factor-b-dependent but does not confer a regulatory phenotype. Blood 2007; 110:2983-2990.

76. Lohmann T, Laue S, Nietzschmann U, Kapellen TM, Lehmann I, Schroeder S, et al. Reduced expression of Th1-associated chemokine receptors on peripheral blood lymphocytes at diagnosis of type 1 diabetes. Diabetes 2002; 51:2474-2480.

77. Rydén A, Faresjö M. Efficient expansion of cryopreserved CD4+CD25+CD1271o/- cells in type 1 diabetes. Res Immunol $2011 ; 1: 36-44$.

78. Akesson K, Tompa A, Ryden A, Faresjo M. Low expression of CD39(+) /CD45RA(+) on regulatory T cells (Treg ) cells in type 1 diabetic children in contrast to high expression of CD101(+) /CD129(+) on Treg cells in children with coeliac disease. Clin Exp Immunol 2015; 180:70-82.

79. Lawson JM, Tremble J, Dayan C, Beyan H, Leslie RDG, Peakman $\mathrm{M}$, et al. Increased resistance of $\mathrm{CD} 4+\mathrm{CD} 25 \mathrm{hi}$ regulatory $\mathrm{T}$ cell-mediated suppression in patients with type 1 diabetes. Clin Exp Immunol 2008; 154:353-359.

80. Schneider A, Rieck M, Sanda S, Pihoker C, Greenbaum C, Buckner JH. The effector T cells of diabetic subjects are resistant to regulation via CD4+FOXP3+regulatory T Cells1. J Immunol 2008; 181:7350-7355.

81. Monti P, Scirpoli M, Maffi P, Piemonti L, Secchi A, Bonifacio E, 
et al. RRapamycin monotherapy in patients with type 1 diabetes modifies CD4+CD25+FOXP3+ regulatory T-cells. Diabetes 2008; 57:2341-2347.

82. Glisic-Milosavljevic S, Waukau J, Jailwala P, Jana S, Khoo HJ, Albertz $\mathrm{H}$, et al. At-risk and recent-onset type 1 diabetic subjects have increased apoptosis in the CD4+CD25+high T-cell fraction. PLoS One 2007; 2:e146.

83. Glisic S, Ehlenbach S, Jailwala P, Waukau J, Jana S, Ghosh S. Inducible regulatory $\mathrm{T}$ cells (iTregs) from recent-onset type 1 diabetes subjects show increased in vitro suppression and higher ITCH levels compared with controls. Cell and tissue research 2010; 339:585-595.

84. Atkinson M, Eisenbarth GS. Type 1 diabetes: new perspectives on disease pathogenesis and treatment. Lancet 2001; 358:221-229.

85. Shan L, Molberg Ø, Parrot I, Hausch F, Filiz F, Gray GM, et al. Structural basis for gluten intolerance in celiac sprue. Science 2002; 297:2275-2279.

86. Kang JY, Kang AH, Green A, Gwee KA, Ho KY. Systematic review: worldwide variation in the frequency of coeliac disease and changes over time. Alimentary pharmacology \& therapeutics 2013 ; 38:226-245.

87. Dieterich W, Ehnis T, Bauer M, Donner P, Volta U, Riecken EO, et al. Identification of tissue transglutaminase as the autoantigen of celiac disease. Nat Med 1997; 3:797-801.

88. van de Wal Y, Kooy Y, van Veelen P, Pena S, Mearin L, Papadopoulos G, et al. Selective deamidation by tissue transglutaminase strongly enhances gliadin-specific $\mathrm{T}$ cell reactivity. J Immunol 1998; 161:1585-1588.

89. Leon F, Sanchez L, Camarero C, Roy G. Cytokine production by intestinal intraepithelial lymphocyte subsets in celiac disease. Digestive diseases and sciences 2005; 50:593-600.

90. Nilsen EM, Jahnsen FL, Lundin KEA, Johansen FE, Fausa O, Sollid LM, et al. Gluten induces an intestinal cytokine response strongly dominated by interferon-g in patients with celiac disease. Gastroenterology 1998; 115:551-563.

91. Lahat N, Shapiro S, Karban A, Gerstein R, Kinarty A, Lerner A. Cytokine profile in coeliac disease. Scand J Immunol 1999; 49:441-446.

92. Hansson T, Dannaeus A, Klareskog L. Cytokine-producing cells in peripheral blood of children with coeliac disease secrete cytokines with a type 1 profile. Clin Exp Immunol 1999; 116:246-250.

93. Monteleone I, Monteleone G, Del Vecchio Blanco G, Vavassori P, Cucchiara $\mathrm{S}$, et al. Regulation of the $\mathrm{T}$ helper cell type 1 transcription factor T-bet in coeliac disease mucosa. Gut 2004; 53:1090-1095.

94. Lahdenperä A, Ludvigsson J, Fälth-Magnusson K, Högberg L, Vaarala $O$. The effect of glute-free diet on Th1-Th2Th3-assocaited intestinal immune repsonses in celiac disease. Scand J Gastroent 2011; 46:538-549.

95. Cianci R, Cammarota G, Frisullo G, Pagliari D, Ianiro G, Martini M. Tissue-infiltrating lymphocytes analysis reveals large modifications of the duodenal "Immunological niche" in coeliac disease after gluten-free diet. Clin Transl Gastroentero 2012; $3: 1-8$.

96. Salvati VM, Mazzarella G, Gianfrani C, Levings MK, Stefanile R, De Giulio B, et al. Recombinant human interleukin 10 suppresses gliadin dependent $\mathrm{T}$ cell activation in ex vivo cultured coeliac intestinal mucosa. Gut 2005; 54:46-53.

97. Zanzi D, Stefanile R, Santagata S, Iaffaldano L, Iaquinto G, Giardullo N, et al. IL-15 interferes with suppressive activity of intestinal regualtory $\mathrm{T}$ cells expanded in Celiac disease. Am $\mathrm{J}$ Gastroenterol 2011; 106:1308-1317.

98. Borrelli M, Salvati VM, Maglio M, Zanzi D, Ferrara K, Santagata $\mathrm{S}$, et al. Immunoregulatory pathways are active in the small intestinal mucosa of patients with potential celiac disease. Am J Gastroenterol 2013; 108:1775-1784.

99. Pham-Short A, Donaghue KC, Ambler G, Phelan H, Twigg S, Craig ME. Screening for Celiac Disease in Type 1 Diabetes: A Systematic Review. Pediatrics 2015; 136:170-176.

100. Joshi AS, Varthakavi PK, Bhagwat NM, Chadha MD, Mittal SS. Coeliac autoimmunity in type I diabetes mellitus. Arab J Gastroenterol 2014; 15:53-57.

101. Patterson CC, Dahlquist GG, Gyurus E, Green A, Soltesz G. Incidence trends for childhood type 1 diabetes in Europe during 1989-2003 and predicted new cases 2005-20: a multicentre prospective registration study. Lancet 2009; 373:2027-2033.

102. Warncke K, Frohlich-Reiterer EE, Thon A, Hofer SE, Wiemann D, Holl RW. Polyendocrinopathy in children, adolescents, and young adults with type 1 diabetes: a multicenter analysis of 28,671 patients from the German/Austrian DPV-Wiss database. Diabetes Care 2010; 33:2010-2012.

103. Elfstrom P, Sundstrom J, Ludvigsson JF. Systematic review with meta-analysis: associations between coeliac disease and type 1 diabetes. Alimentary pharmacology \& therapeutics 2014; 40:1123-1132.

104. d'Annunzio G, Giannattasio A, Poggi E, Castellano E, Calvi A, Pistorio A, et al. Beta-cell autoimmunity in pediatric celiac disease: the case for routine screening? Diabetes Care 2009; 32:254-256.

105. Sollid LM, Markussen G, Ek J, Gjerde H, Vartdal F, Thorsby E. Evidence for a primary association of celiac disease to a particular HLA-DQ alpha/beta heterodimer. J Exp Med 1989; 169:345-350.

106. Liu E, Lee HS, Aronsson CA, Hagopian WA, Koletzko S, Rewers MJ, et al. Risk of pediatric celiac disease according to HLA haplotype and country. N Engl J Med 2014; 371:42-49.

107. Bao F, Yu L, Babu S, Wang T, Hoffenberg EJ, Rewers M, et al. One third of HLA DQ2 homozygous patients with type 1 diabetes express celiac disease-associated transglutaminase autoantibodies. J Autoimmun 1999; 13:143-148.

108. Kuitunen M, Saukkonen T, Ilonen J, Akerblom HK, Savilahti E. Intestinal permeability to mannitol and lactulose in children with type 1 diabetes with the HLA-DQB $1 * 02$ allele. Autoimmunity 2002; 35:365-368.

109. Hadley D, Hagopian W, Liu E, She JX, Simell O, Akolkar B, et al. HLA-DPB $1 * 04: 01$ Protects Genetically Susceptible Children from Celiac Disease Autoimmunity in the TEDDY Study. Am J Gastroenterol 2015; 110:915-920.

110. Smyth DJ, Plagnol V, Walker NM, Cooper JD, Downes K, Yang $\mathrm{JH}$, et al. Shared and distinct genetic variants in type 1 diabetes and celiac disease. N Engl J Med 2008; 359:2767-2777.

111. Pocecco M, Ventura A. Coeliac disease and insulin-dependent diabetes mellitus: a causal association? Acta Pediatr 1995; 84:1432-1433.

112. Cosnes J, Cellier C, Viola S, Colombel JF, Michaud L, Sarles J, et 
$a l$. Incidence of autoimmune diseases in celiac disease: protective effect of the gluten-free diet. Clinical gastroenterology and hepatology: the official clinical practice journal of the American Gastroenterological Association 2008; 6:753-758.

113. Hoorfar J, Buschard K, Dagnaes-Hansen F. Prophylactic nutritional modification of the incidence of diabetes in autoimmune non-obese diabetic (NOD) mice. Br J Nutrit 1993; 69:597-607.

114. Funda DP, Kaas A, Tlaskalova-Hogenova H, Buschard K. Gluten-free but also gluten-enriched (gluten+) diet prevent diabetes in NOD mice; the gluten enigma in type 1 diabetes. Diabetes Metab Res Rev 2008; 24:59-63.

115. Pastore MR, Bazzigaluppi E, Belloni C, Arcovio C, Bonifacio E, Bosi E. Six months of gluten-free diet do not influence autoantibody titers, but improve insulin secretion in subjects at high risk for type 1 diabetes. J Clin Endocrinol Metab 2003; 88:162-165.

116. Fuchtenbusch M, Ziegler AG, Hummel M. Elimination of dietary gluten and development of type 1 diabetes in high risk subjects. The review of diabetic studies: RDS 2004; 1:39-41.

117. Hummel M, Bonifaco E, Naserke HE, Ziegler AG. Eliminiation of dietary gluten does not reduce titers of tyep 1 diabetes-associated autoantibodies in high-risk subjects. Diabetes Care 2002; 25:1111-1116.

118. Hummel S, Pfluger M, Hummel M, Bonifacio E, Ziegler AG. Primary dietary intervention study to reduce the risk of islet autoimmunity in children at increased risk for type 1 diabetes: the BABYDIET study. Diabetes Care 2011; 34:1301-1305.

119. Beyerlein A, Chmiel R, Hummel S, Winkler C, Bonifacio E, Ziegler AG. Timing of gluten introduction and islet autoimmunity in young children: updated results from the BABYDIET study. Diabetes Care 2014; 37:e194-195.

120. Simmons JH, Klingensmith GJ, McFann K, Rewers M, Ide LM, Taki I, et al. Celiac autoimmunity in children with type 1 diabetes: a two-year follow-up. J Pediatr 2011; 158:276-281.

121. Saukkonen T, Väisnän S, Åkerblom HK, Savilahti E. Coeliac disease in children and adolescents with type 1 diabetes: a study of growth, glycaemic control, and experiences of families. Acta Paediatrica 2002; 91:297-302.

122. Scaramuzza AE, Mantegazza C, Bosetti A, Zuccotti GV. Type 1 diabetes and celiac disease: The effects of gluten free diet on metabolic control. World J Diabetes 2013; 4:130-134.

123. Klemetti P, Savilathi E, Ilonen J, Åkerblom HK, Vaarala O. T-cell reactivity to wheat gluten in patients with insulin-dependent diabetes mellitus. Scand J Immunol 1998; 47:48-53.

124. Mojibian M, Chakir H, Lefebvre DE, Crookshank JA, Sonier B, Keely E, et al. Diabetes-specific HLA-DR-restricted proinflammatory $\mathrm{T}$-cell response to wheat polypeptides in tissue transglutaminase antibody-negative patients with type 1 diabetes. Diabetes 2009; 58:1789-1796.

125. Westerholm-Ormio M, Vaarala O, Pihkala P, Ilonen J, Savilahti E. Immunologic activity in the small intestinal mucosa of pediatric patients with type 1 diabetes. Diabetes 2003; 52:2287-2295.

126. Tiittanen M, Westerholm-Ormio M, Verkasalo M, Savilahti E,
Vaarala O. Infiltration of forkhead box P3-expressing cells in small intestinal mucosa in coeliac disease but not in type 1 diabetes. Clin Exp Immunol 2008; 152:498-507.

127. Savilahti E, Örmälä T, Saukkonen T, Sandini-Pohjavuori U, Kantele JM, Arato A. Jejuna of patients with insulin-dependent diabetes mellitus (IDDM) show signs of immune activation. Clin Exp Immunol 1999; 116:70-77.

128. Atkinson MA, Bowman MA, Kao KJ, Campbell L, Dush PJ, Shah $\mathrm{SC}$, et al. Lack of immune responsiveness to bovine serum albumin in insulin-dependent diabetes. N Engl J Med 1993; 329:1853-1858.

129. Åkerblom HK, Vaarala O. Cow milk proteins, autoimmunity and Type 1 diabetes. Exp Clin Endocrinol Diabetes 1997; 105:83-85.

130. Kolb H, Pozzilli P. Cow's milk and type 1 diabetes: the gut immune system deserves attention. Immunol Today 1999; 20:108-110.

131. Fälth-Magnusson K, Jansson G, Stenhammar L, Magnusson K-E. Serum food antibodies analysed by enzyme-linked immunosorbent assay (ELISA) and diffusion-in-gel (DIG)-ELISA methods in children with and without celiac disease. J Ped Gastro Nutri 1994; 18:56-62.

132. Nilsson L, Kivling A, Jalmelid M, Fälth Magnusson K, Faresjö M: Combinations of common chronic paediatric diseases deviate the immune response in diverging directions. Clin Exp Immunol 2006; 146:433-442.

133. Kivling A, Nilsson L, Fälth-Magnusson K, Söllvander S, Johanson C, Faresjö M. Diverse FOXP3 expression in children with type 1 diabetes and celiac disease. Ann NY Acad Sci 2008; 1150:273-277.

134. Auricchio R, Paparo F, Maglio M, Franzese A, Lombardi F, Valerio $\mathrm{G}$, et al. In vitro-deranged intestinal immune response to gliadin in type 1 diabetes. Diabetes 2004; 53:1680-1683.

135. Vorobjova T, Uibo O, Heilman K, Rago T, Honkanen J, Vaarala $\mathrm{O}$, et al. Increased FOXP3 expression in small-bowel mucosa of children with coeliac disease and type 1 diabetes mellitus. Scand J Gastroent 2009; 44:422-430.

136. Vorobjova T, Uibo O, Heilman K, Uibo R. Increased density of tolerogenic dendritic cells in the small bowel mucosa of celiac patients. World J Gastroenterol 2015; 21:439-452.

137. Vorobjova T, Uibo O, Ojakivi I, Teesalu K, Panarina M, Heilman $\mathrm{K}$, et al. Lower expression of tight junction protein 1 gene and increased FOXP3 expression in the small bowel mucosa in coeliac disease and associated type 1 diabetes mellitus. Int Arch Allergy Immunol 2011; 156:451-461.

138. Uibo R, Panarina M, Teesalu K, Talja I, Sepp E, Utt M, et al. Celiac disease in patients with type 1 diabetes: a condition with distinct changes in intestinal immunity? Cell Mol Immunol 2011; 8:150-156.

139. Velthuis JH, Unger WW, van der Silk AR, Duinkerken G, Engelse $\mathrm{M}$, Schaapherder AF, et al. Accumulation of autoreactive effector $\mathrm{T}$ cells and allo-specific regualtory $\mathrm{T}$ cells in the pancreas allograft of a type 1 diabetic recipient. Diabetologia 2009; 52:494-503. 